\title{
Analisa Feature Citra Darah Menggunakan Metode Histogram
}

\author{
Feature Analysis Of Blood Image Using Histogram Method
}

\author{
Supatman \\ Teknik Informatika, Fakultas Teknologi Informasi \\ Universitas Mercu Buana Yogyakarta. \\ E-mail: keliksupatman@gmail.com
}

\begin{abstract}
ABSTRAK
Darah manusia adalah cairan di dalam tubuh yang berfungsi untuk mengangkut oksigen yang diperlukan oleh sel-sel di seluruh tubuh. Sistem A-B-O mengolongkan darah menjadi 4 golongan yaitu A, AB, B dan O. Identifikasi golongan darah dilakukan dengan tes antigen pada sampel darah yang akan diujinya. Teknologi pengolahan image memungkinkan identifikasi dilakukan dengan analisa citra darah dengan pendekatan warna. Dengan ciri/feature histogram yaitu rata-rata, standar deviasi, varian, entropy, skewness dan kurtosisi dapat dilakukan analisa terhadap warna darah yang dapat mengidentifikasi golongan darah sesuai dengan sistem AB-O. Hasil analisa feature : rata-rata, standar deviasi, varian, entropy, skewness dan kurtosisi memberikan hasil : Ciri rata-rata dari histogram tidak dapat memberikan nilai gap antara golongan darah A, AB, B dan O; Semakin tinggi/besar size dari resolusi citra maka nilai ciri ciri rata-rata, standar deviasi, varian, entropy semakin besar kecuali skewness dan kurtosis berbanding terbalik dengan resolusinya ; Ciri standar deviasi, varian, entropy, skewness dan kurtosis memberikan nilai gap antara golongan darah $\mathrm{A}, \mathrm{AB}, \mathrm{B}$ dan $\mathrm{O}$ sehingga dapat dipergunakan sebagai ciri maupun vektor ciri dalam identifikasi citra golongan darah; uji beda rerata dari vektor ciri yang terdiri dari standar deviasi, varian, entropy, skewness dan kurtosis antara Golongan Darah A, AB, B dan O memiliki beda rata-rata yang signifikan lebih kecil dari 0.05 .
\end{abstract}

Kata Kunci : Darah, Citra, Histogram

\begin{abstract}
Human blood is a fluid in the body that serves to transport the oxygen needed by cells throughout the body. The A-B-O system classifies blood into 4 groups: A, AB, B and O. Blood type identification is performed by antigen tests on blood samples to be tested. Image processing technology allows identification to be done by analyzing blood images with a color approach. With the feature / feature histogram that is average, standard deviation, variant, entropy, skewness and kurtosisi can be analyzed to the color of blood that can identify blood type according to system A-B-O. Feature analysis: average, standard deviation, variant, entropy, skewness and kurtosisi give results: The average characteristic of the histogram can not give the gap value between blood types $\mathrm{A}, \mathrm{AB}, \mathrm{B}$ and $\mathrm{O}$; The higher / larger size of the image resolution the average characteristic value, standard deviation, variant, entropy is greater except skewness and kurtosis inversely with the resolution; The standard features of deviation, variant, entropy, skewness and kurtosis provide the gap value between Blood Type $\mathrm{A}, \mathrm{AB}, \mathrm{B}$ and $\mathrm{O}$ so that it can be used as a characteristic or vector characteristic in the identification of blood type image; the mean difference test of the characteristic vector comprising standard deviation, variant, entropy, skewness and kurtosis between Blood Group A, AB, B and $\mathrm{O}$ has a significant mean difference smaller than 0.05.
\end{abstract}

Keywords: Blood, Image, Histogram 


\section{PENDAhULUAN}

Darah manusia adalah cairan di dalam tubuh yang berfungsi untuk mengangkut oksigen yang diperlukan oleh sel-sel di seluruh tubuh. Darah juga menyuplai jaringan tubuh dengan nutrisi, mengangkut zat-zat sisa metabolisme, dan mengandung berbagai bahan penyusun sistem imun yang bertujuan mempertahankan tubuh dari berbagai penyakit. Hormon-hormon darisistem endokrinjuga diedarkan melalui darah.

Darah manusia berwarna merah, antara merah terang apabila kaya oksigen sampai merah tua apabila kekurangan oksigen. Warna merah pada darah disebabkan

oleh hemoglobin, protein

pernapasan (respiratory protein) yang mengandung besi dalam bentuk heme, yang merupakan tempat terikatnya molekul-molekul oksigen

Analisa melalui citra yang dikembangkan berdasarkan pada perubahan virtual objek dapat dihasilkan data yang berisikan gambar yang memberikan beberapa informasi seperti tekstur, warna, bentuk, jumlah dan letak benda secara bersama-sama yang bertujuan untuk menggantikan fungsi mata manusia (human eye) dalam mengidentifikasi benda yang dimaksud, sehingga tingkat kesalahan akibat kelelahan mata dapat dihilangkan dan dalam pengambilan keputusan dapat lebih akurat dan konsisten.

Citra darah yang merupakan hasil akuisi darah dapat dianalisa berdasarkan menggunakan metode histogram yang merupakan grafik distribusi piksel dengan berbagai feature. Feature-feature hasil ekstraksi citra darah dapat memberikan informasi menggenai berbagai hal terkait dengan kondisi fisik seseorang.

Penelitian analisa feature citra darah menggunakan metode histogram ini bertujuan menganalisa feature/pola hasil ekstraksi metode histogram untuk mendefinisikan berbagai bentuk pola sebagai data masukkan identifikasi dan atau klasifikasi maupun klusterisasi.

\section{TINJAUAN PUSTAKA}

\subsection{Darah}

Darah manusia adalah cairan di dalam tubuh yang berfungsi untuk engangkut oksigen yang diperlukan oleh sel-sel di seluruh tubuh. Darah juga menyuplai jaringan tubuh dengan nutrisi, mengangkut zat-zat sisa metabolisme, dan mengandung berbagai bahan penyusunsistem imun yang bertujuan mempertahankan tubuh dari berbagai penyakit. Hormon-hormon darisistem endokrinjuga diedarkan melalui darah.

Darah manusia berwarna merah, antara merah terang apabila kaya oksigen sampai merah tua apabila kekurangan oksigen. Warna merah pada darah disebabkan oleh hemoglobin, protein pernapasan (respiratory protein) yang mengandung besi dalam bentuk heme, yang merupakan tempat terikatnya molekul-molekul oksigen.

Tipe golongan darah yang disebut system $A-B-O$, telah ditemukan pada tahun 1901. Beberapa tahun kemudian dimulai pada tahun 1937, reaksi antigen-antibodi dalam darah ditemukan, dimana yang sering ditemukan adalah factor $A B H, M n, R h$ dan Gm (diantara lebih dari 100 antigen yang ada).Kebanyakan orang hanya mengenal factor Rh (Rhesus factor), yang secara teknis disebut D-antigen. Ada lebih dari 256 antigen dan 23 sistem penggolongan darah yang didasarkan pada antigen tersebut. Antigen adalah struktur kimia yang melekat pada permukaan sel darah merah. Sedangkan antibody adalah protein yang mengambang pada cairan darah (terutama serum yang berhubungan dengan factor kloting/pembeku darah). Karena suatu individu kadang mengamai alergi atau infeksi oleh agen penyakit (TB, smallpox 
dan hepatitis), sehingga substansi tersebut aktif melawannya. Prinsip dasar dari serologi adalah setiap ada antigen akan terbentuk terbentuk antibody yang spesifik. Sehingga dengan demikian "sетиa golongan darah didefinisikan sebagai antigen pada sel darah merahnya dan ada antibody terhadap antigen tersebut didalam serumnya".

Tabel 1. Golongan darah, antigen dan antibodinya (Darmono).

\begin{tabular}{ccl}
\hline $\begin{array}{c}\text { Golongan } \\
\text { darah }\end{array}$ & $\begin{array}{c}\text { Antigen } \\
\text { padasel } \\
\text { darah } \\
\text { merah }\end{array}$ & $\begin{array}{c}\text { Antibody dalam } \\
\text { serum }\end{array}$ \\
\hline$A$ & $A$ & Anti-B \\
$B$ & $B$ & Anti-A \\
$A B$ & $A B$ & $\begin{array}{l}\text { Bukan anti- } \\
\text { Alanti-B } \\
\end{array}$ \\
$O$ & $O$ & Anti-A/anti-B \\
\hline
\end{tabular}

\subsection{Citra}

Citra (image -istilah lain untuk gambar- sebagai salah satu komponen multimedia yang memegang peranan penting sebagai bentuk informasi visual. Citra mempunyai karakteristik yang tidak dimiliki oleh data teks, yaitu citra kaya dengan informasi. Ada sebuah peribahasa yang berbunyi "sebuah gambar bermakna lebih dari seribu kata". Maksudnya tentu sebuah gambar dapat memberikan informasi yang lebih banyak daripada informasi tersebut disajikan dalam bentuk kata-kata (Munir, Rinaldi, 2004).

Secara harafiah, citra adalah gambar pada bidang dwimatra (dua dimensi). Ditinjau dari sudut pandang matematis, citra merupakan fungsi menerus (continue) dari intensitas cahaya pada bidang dwimatra. Sumber cahaya menerangi objek, objek memantulkan kembali sebagian dari berkas cahaya tersebut. Pemantulan cahaya ini ditangkap oleh alat-alat optik, misalnya mata pada manusia, kamera, pemindai (scanner), dan sebagainya, sehingga bayangan objek yang disebut citra tersebut terekam Secara matematis fungsi intensitas cahaya pada bidang dwimatra disimbolkan dengan $f(x, y)$ yang dalam hal ini (Munir, Rinaldi, 2004):

$(x, y)$ : koordinat pada bidang dwimatra

$f(x, y):$ intensitas cahaya (brightness) pada titik $(x, y)$

Nilai $f(x, y)$ adalah hasil kali dari:

1. $i(x, y)=$ jumlah cahaya yang berasal dari sumbernya (illumination), nilainya 0 sampai tidak terhingga, dan

2. $r(x, y)=$ derajat kemampuan objek memantulkan cahaya (reflection) nilainya antara 0 dan 1.

Gambar 1. memperlihatkan proses pembentukan intensitas cahaya. Sumber cahaya menyinari permukaan objek. Jumlah pancaran (iluminasi) cahaya yang diterima objek pada koordinat $(x, y)$ adalah $i(x, y)$. Objek memantulkan cahaya yang diterimanya dengan derajat pemantulan $r(x, y)$. Hasil kali antara $i(x, y)$ dan $r(x, y)$ menyatakan intensitas cahaya pada koordinat $(x, y)$ yang ditangkap oleh sensor visual pada sistem optik.

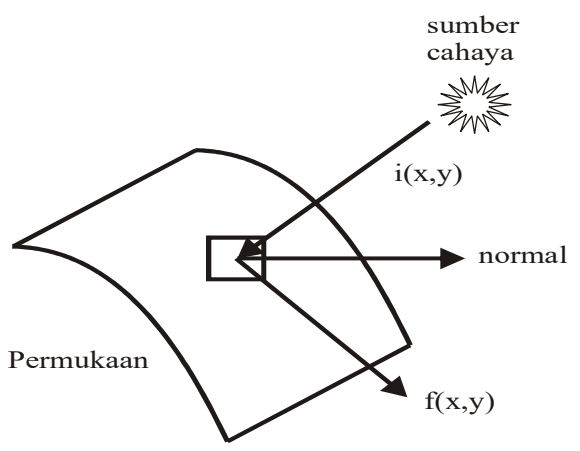

Gambar 1. Pemantulan Citra (Warni,2009)

Citra sebagai keluaran dari suatu sistem perekaman dapat bersifat (Warni, 2009):

1. Optik berupa foto.

2. Analog berupa sinyal video seperti gambar pada monitor televisi. 
3. Digital yang dapat langsung disimpan pada suatu pita magnetik.

Citra yang dimaksudkan dalam skripsi ini adalah "citra diam" (still image). Citra diam adalah citra tunggal yang tidak bergerak. Citra bergerak (moving images) adalah rangkaian citra diam yang ditampilan secara beruntun (sekuensial) sehingga memberi kesan pada mata sebagai gambar yang bergerak. Setiap citra didalam rangkaian itu disebut frame. Gambargambar yang tampak pada film layar lebar atau televisi pada hakikatnya terdiri atas ratusan sampai ribuan frame.

\subsection{Histogram}

Histogram citra adalah grafik yang menggambarkan penyebaran nilai-nilai intensitas pixel dari suatu citra atau bagian tertentu di dalam citra. Histogram juga dapat menunjukkan banyak hal tentang kecerahan (brightness) dan kontras (contrast) dari sebuah gambar. Secara grafis histogram ditampilkan dengan diagram batang, misal citra digital memiliki L derajat keabuan. (misalnya citra dengan kuantisasi derajat keabuan 8-bit, nilai derajat keabuan dari 0 255) . Histogram juga memberi informasi mengenai kontras sebuah citra. Histogram yang terkumpul pada sisi kiri menunjukkan bahwa citra memiliki kontras rendah dan cenderung gelap, sedangkan histogram yang terkumpul pada sisi kanan memberikan informasi bahwa citra tersebut mempunyai kontras rendah dan cenderung terang (overexposure).

Citra dengan kontras yang baik mempunyai histogram yang merata pada seluruh nilai aras keabuan. Untuk citra berwarna, histogramnya dinyatakan untuk setiap komponen $R G B \quad$ (Red, Blue, Green) yang membentuk setiap piksel citranya. Dengan demikian untuk setiap citra berwarna dapat dibuat tiga buah histogram.

\subsection{Ciri Histogram}

Ciri histogram didasarkan pada histogram dari suatu citra. Bila $x$ menyatakan tingkat keabuan pada suatu citra, maka probabilitas dari $x$ dinyatakan dengan:

$$
\begin{gathered}
P(x)=\frac{\text { Banyaknya titik keabuan } x}{\text { total titik suatu citra }} \\
x=0, \ldots, L-1
\end{gathered}
$$

Beberapa ciri histogram yang dapat dihitung, antara lain:

$$
\begin{aligned}
& \text { Moments }: m_{i}=E\left[u^{i}\right]=\sum_{x=0}^{L} x^{i} P(x) \quad i=1,2, \ldots \\
& \text { Absolut Moments }: \hat{m}_{i}= \\
& E\left[|u|^{i}\right]=\sum_{x=0}^{L}|x|^{i} P(x) \\
& \text { Pusat Moments : } \mu_{i}= \\
& E\left[[u-E(u)]^{i}\right]=\sum_{x=0}^{L}\left(x-m_{1}\right)^{i} P(x) \\
& \text { Absolut Pusat Moments : } \hat{\mu}_{i}= \\
& E\left[u-\left.E(u)\right|^{i}\right]=\sum_{x=0}^{L}\left|x-m_{1}\right|^{i} P(x) \\
& \text { Entropi : } H= \\
& E\left[-\log _{2} P(x)\right]=-\sum_{x=0}^{L} P(x) \log _{2} P(x) \text { bits } \\
& S \tan \text { dar Deviasi : dispersion }=\hat{\mu}_{1} \\
& \text { Rata - Rata : mean }=m_{1} \\
& \text { Variance } \quad=\mu_{2} \\
& \text { Nilai mean Square }=m_{2} \\
& \text { Skewness } \quad=\mu_{3} \\
& \text { Kurtosis } \quad=\mu_{4}-3
\end{aligned}
$$

\section{METODOLOGI PENELITIAN}

\subsection{Materi}

Data citra darah menggunakan format JPG dengan size $25 \times 25$ pixel, $50 \times 50$ pixel, $100 \times 100$ pixel

\subsection{Peralatan}

\subsubsection{Perangkat Keras}

Notebook intel i3, harddisk 320GB memori, harddisk, memori 4Gbyte RAM dan sistem operasi Microsoft Windows 7 Profesional untuk membuat program dan pembuatan laporan penelitian. 


\subsubsection{Perangkat Lunak}

Perangkat lunak yang digunakan dalam penelitian ini ada tiga macam, yaitu:

a) Software Matlab versi 7.10.0 (R2010a)

b) Photoshop versi CS5

c) Microsoft office picture manager

\subsection{Jalannya Penelitian}

Metodologi pada penelitian ini, diusulkan secara diagram blok sebagaimana pada Gambar 2. di bawah ini yang merupakan urutan pekerjaan yang akan dilakukan.

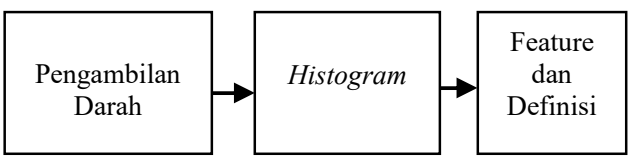

Gambar 2. Blok diagram langkah kerja sistem analisis citra darah.

\section{PEMBAHANSAN}

\subsection{Data Citra Darah}

Data citra darah dengan format $J P G$ dengan size $25 \times 25$ pixel. Gambar data citra darah ditunjukkan pada Gambar 3.

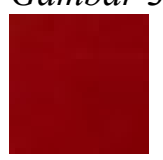

Gol

Darah

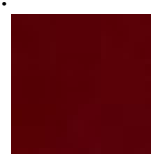

Gol

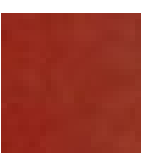

Gol

Darah

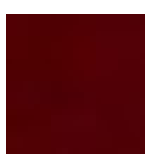

Gol

Darah
O

Gambar 3. Data Citra Darah

\subsection{Layer $R$ (red)}

Proses pemisahan layer yaitu layer $R$ (red), layer G(green), layer $B$ (blue), dengan layer $R$ ditunjukkan pada Gambar 4.

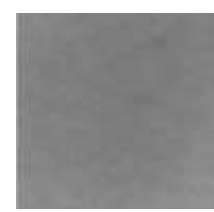

Gambar 4. Citra Layer R

\subsection{Histogram Citra Darah}

Histogram Citra Darah A, AB, B dan $O$, secara berturut ditunjukkan pada Gambar 5a, 5b, 5c dan 5d.

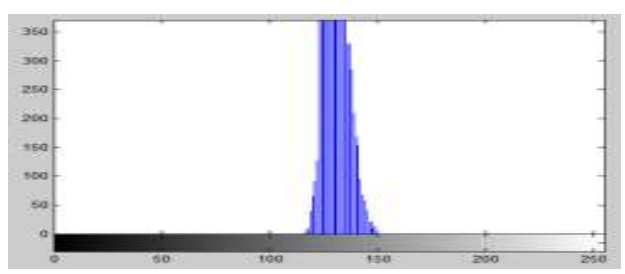

Gambar 5a. Histogram Gol Darah A

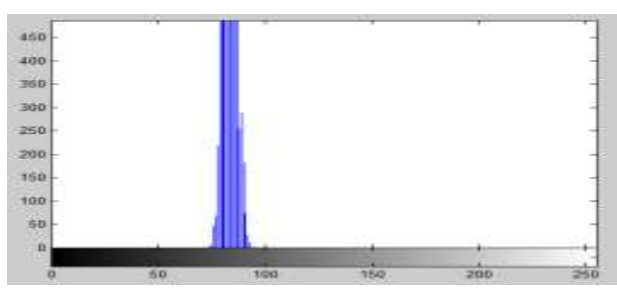

Gambar 5b. Histogram Gol Darah AB

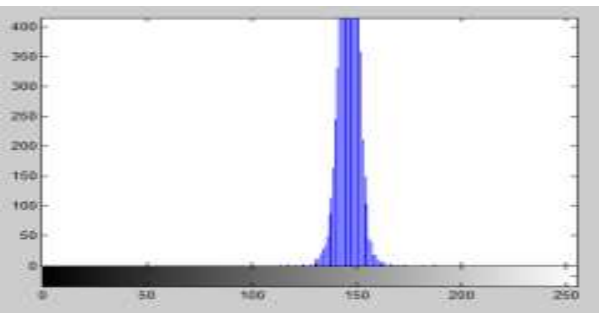

Gambar 5c. Golongan Darah B

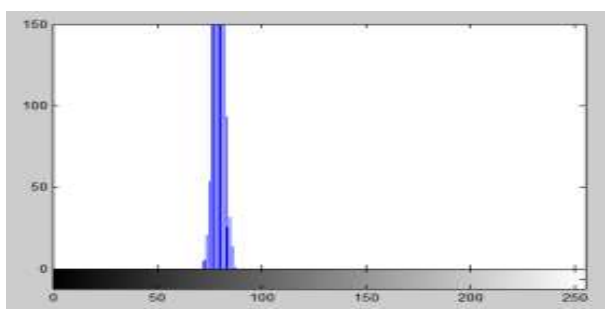

Gambar 5d. Golongan Darah O

\subsection{Data Ektrasi Ciri}

Data dari ekstraksi ciri dari histogram dengan ciri rata-rata, standar deviasi, varian, entropy, skewness dan kurtosis dengan nilai rerata untuk size $25 \times 25$ pixel, $50 \times 50$ pixel dan $100 \times 100$ pixel, secara berturut-turut ditunjukkan pada Tabel 1, Tabel 2 dan Tabel 3. 
Tabel 1. Ciri rata-rata, standar deviasi, varian, entropy, skewness dan kurtosis dengan nilai rerata untuk size $25 \times 25$ pixel.

\begin{tabular}{ccccccc}
\hline Gol. Darah & Rata-rata & Deviasi & Varian & Entropy & Skewness & Kurtosis \\
$A$ & 2,44 & 12,52 & 157,15 & 0,33 & 5,86 & 38,81 \\
$A B$ & 2,44 & 13,09 & 180,75 & 0,35 & 6,13 & 44,31 \\
$B$ & 2,44 & 11,35 & 130,62 & 0,46 & 5,51 & 34,66 \\
$O$ & 2,44 & 15,03 & 226,89 & 0,31 & 7,47 & 62,36 \\
\hline
\end{tabular}

Tabel 2. Ciri rata-rata, standar deviasi, varian, entropy, skewness dan kurtosis dengan nilai rerata untuk size $50 \times 50$ pixel.

\begin{tabular}{ccccccc}
\hline Gol. Darah & Rata-rata & Deviasi & Varian & Entropy & Skewness & Kurtosis \\
\hline$A$ & 9,76 & 43,85 & 1932,82 & 0,45 & 5,12 & 29,92 \\
$A B$ & 9,76 & 48,68 & 2480,47 & 0,42 & 5,82 & 39,73 \\
$B$ & 9,76 & 45,23 & 2056,51 & 0,50 & 5,29 & 31,31 \\
$O$ & 9,76 & 55,47 & 3083,90 & 0,38 & 6,92 & 53,54 \\
\hline
\end{tabular}

Tabel 3. Ciri rata-rata, standar deviasi, varian, entropy, skewness dan kurtosis dengan nilai rerata untuk size $100 \times 100$ pixel.

\begin{tabular}{ccccccc}
\hline Gol. Darah & Rata-rata & Deviasi & Varian & Entropy & Skewness & Kurtosis \\
\hline$A$ & 39,06 & 146,45 & 21456,63 & 0,56 & 4,29 & 21,50 \\
$A B$ & 39,06 & 186,96 & 35607,61 & 0,31 & 5,72 & 37,91 \\
$B$ & 39,06 & 171,73 & 29654,71 & 0,60 & 4,98 & 27,90 \\
$O$ & 39,06 & 171,42 & 29442,30 & 0,52 & 5,08 & 29,79 \\
\hline
\end{tabular}

\subsection{Analisa}

\subsubsection{Analisa Gap}

Analisa Gap dilakukan dengan menghitung nilai absolut dari selisih feature, ditunjukan pada Tabel 4.

Tabel 4. Gap Ciri Rata-Rata Citra Size $25 \times 25$

\begin{tabular}{ccccc}
\hline $\begin{array}{c}\text { Gol } \\
\text { Darah }\end{array}$ & $A$ & $A B$ & $B$ & $O$ \\
\hline$A$ & 0,0000 & 0,0000 & 0,0000 & 0,0000 \\
$A B$ & 0,0000 & 0,0000 & 0,0000 & 0,0000 \\
$B$ & 0,0000 & 0,0000 & 0,0000 & 0,0000 \\
$O$ & 0,0000 & 0,0000 & 0,0000 & 0,0000 \\
\hline
\end{tabular}

Tabel 5 Gap Ciri Standar Deviasi Citra Size $25 \times 25$

\begin{tabular}{ccccc}
\hline \multicolumn{5}{c}{$25 \times 25$} \\
Darah & $A$ & $A B$ & $B$ & $O$ \\
\hline$A$ & 0,0000 & 0,5782 & 1,1703 & 2,5119 \\
$A B$ & 0,5782 & 0,0000 & 1,7484 & 1,9337 \\
$B$ & 1,1703 & 1,7484 & 0,0000 & 3,6821 \\
$O$ & 2,5119 & 1,9337 & 3,6821 & 0,0000 \\
\hline
\end{tabular}

Tabel 6. Gap Ciri Varian Citra Size $25 \times 25$ 


\begin{tabular}{|c|c|c|c|c|}
\hline \multicolumn{5}{|c|}{ Tabel 7 Gap Ciri Entropy Citra Size $25 \times 25$} \\
\hline $\begin{array}{c}\text { Gol } \\
\text { Darah }\end{array}$ & $A$ & $A B$ & $B$ & $O$ \\
\hline$A$ & 0,0000 & 0,0110 & 0,1282 & 0,0248 \\
\hline$A B$ & 0,0110 & 0,0000 & 0,1172 & 0,0358 \\
\hline$B$ & 0,1282 & 0,1172 & 0,0000 & $0,1530^{-}$ \\
\hline$O$ & 0,0248 & 0,0358 & 0,1530 & 0,0000 \\
\hline \multicolumn{5}{|c|}{$\begin{array}{c}\text { Tabel } 8 \text { Gap Ciri Skewness Citra Size } 25 x \\
25\end{array}$} \\
\hline $\begin{array}{c}\text { Gol } \\
\text { Darah }\end{array}$ & $A$ & $A B$ & $B$ & $O$ \\
\hline$A$ & 0,0000 & 0,2678 & 0,3520 & 1,6045 \\
\hline$A B$ & 0,2678 & 0,0000 & 0,6199 & 1,3366 \\
\hline$B$ & 0,3520 & 0,6199 & 0,0000 & 1,9565 \\
\hline$O$ & 1,6045 & 1,3366 & 1,9565 & 0,0000 \\
\hline
\end{tabular}

Tabel 9 Gap Ciri Kurtosis Citra Size $25 \times 25$

\begin{tabular}{ccccc}
\hline $\begin{array}{c}\text { Gol } \\
\text { Darah }\end{array}$ & $A$ & $A B$ & $B$ & $O$ \\
\hline$A$ & 0,0000 & 5,4988 & 4,1441 & 23,5573 \\
$A B$ & 5,4988 & 0,0000 & 9,6430 & 18,0584 \\
$B$ & 4,1441 & 9,6430 & 0,0000 & 27,7014 \\
$O$ & 23,5573 & 18,0584 & 27,7014 & 0,0000 \\
\hline
\end{tabular}

\subsection{Pembahasan}

Bedasarkan Tabel 4.1 Ciri ratarata dari histogram tidak dapat memberikan nilai gap antara golongan darah $A, A B, B$ dan $O$ hal ini dikarena nilai gapnya adalah nol atau 0,0000.

Berdasarkan Tabel 5, Tabel 6, Tabel 7, Tabel 8 dan Tabel 9, deviasi, varian, entropy, skewness dan kurtosis memberikan nilai gap antara golongan darah $A, A B, B$ dan $O$ sehingga dapat dipergunakan sebagai ciri maupun vektor ciri dalam identifikasi citra golongan darah untuk pengolahan baik deteksi maupun identifikasi sistem.

Berdasarkan keluaran olah data pada Tabel 10 diperoleh nilai P-value sebesar 0,0055592 lebih kecil dari alfa $(0,05)$ sehingga secara statistik pada alfa $5 \%$ dan berdasarkan ciri standar deviasi, varian, entropy, skewness dan

Gol Darah

$\begin{array}{lllll}A & 0,0000 & 23,6034 & 26,5268 & 69,7351\end{array}$

$A B \quad 23,6034 \quad 0,0000 \quad 50,1302 \quad 46,1317$

$\begin{array}{lllll}B & 26,5268 & 50,1302 & 0,0000 & 96,2619\end{array}$

$\begin{array}{lllll}O & 69,7351 & 46,1317 & 96,2619 & 0,0000\end{array}$

kurtosis maka Golongan Darah $A, A B, B$ dan O secara signifikan berbeda

Berdasarkan keluaran olah data pada Tabel 10 diperoleh nilai P-value sebesar 0,0320907 lebih kecil dari alfa $(0,05)$ sehingga secara statistik pada alfa $5 \%$ dan berdasarkan ciri standar deviasi, varian, entropy, skewness dan kurtosis maka Golongan Darah A, AB, B dan $O$ secara signifikan berbeda.

Berdasarkan keluaran olah data pada Tabel 10 diperoleh nilai P-value sebesar 0,03735923 lebih kecil dari alfa $(0,05)$ sehingga secara statistik pada alfa $5 \%$ dan berdasarkan ciri standar deviasi, varian, entropy, skewness dan kurtosis maka Golongan Darah $A, A B, B$ dan O secara signifikan berbeda.

\section{KESIMPULAN}

Berdasarkan analisa dan pembahasan dari ciri histogram yang terdiri dari ciri rata-rata, standar deviasi, varian, entropy, skewness dan kurtosis maka dapat diambil kesimpulan sebagai berikut :

a) Ciri rata-rata dari histogram tidak dapat memberikan nilai gap antara golongan darah $A, A B, B$ dan $O$.

b) Ciri standar deviasi, varian, entropy, skewness dan kurtosis memberikan nilai gap antara golongan darah $A, A B, B$ dan $O$ sehingga dapat dipergunakan sebagai ciri maupun vektor ciri dalam identifikasi citra golongan darah.

c) Berdasarkan uji beda rerata dari vektor ciri yang terdiri dari standar deviasi, varian, entropy, skewness dan kurtosis antara Golongan Darah $A, A B, B$ dan $O$ memiliki beda rata-rata yang signifikan lebih kecil dari 0.05 . 


\section{DAFTAR PUSTAKA}

Darmono, "Serologi Forensic", www.geocities.ws/kuliah_farm/fa rmasi_forensik/

Serologi forensic.doc, diakses tanggal 20 Januari 2016

Duda., Ricard O, Hart., Peter E, Stork., Peter E, 2000, "Pattern Clasification", John Willey \& Sons Inc.

Warni, Elly, 2009, "Penentuan Morfologi Sel Darah Merah (Eritrosit) Berbasis Pengolahan Citra dan Jaringan Syaraf Tiruan", Jurnal Ilmiah Enjiniring, UNHAS, Vol 7/No. 03/OktoberDesember/2009

Fitryadi, Khairil., Sutikno, 2016, "Pengenalan Golongan Darah Menggunakan Jaringan Syaraf Tiruan Perceptron", Jurnal Masyarakat Informatika, Volume 7, Nomor 1, ISSN 2086-4930.

Pratt., William K., 2001, "Digital Image Processing”, John Willey \& Sons.
Putra., Darma, 2009, "Sistem Biometrika, Konsep Dasar, Teknik Analisis Citra, dan Tahapan Membangun Aplikasi Biometrika", C.V. Andi Offset, Yogyakarta.

Munir., Rinaldi, 2004, "Pengolahan Citra Digital Dengan Pendekatan Algoritmik", Informatika, Bandung.

Russ., John C., 1998, "The Image Processing Handbook 3th", A CRC Handbook Published.

Steinmetz., Raft, Nahrstedt., Klara, 2002, "Multimedia Fundamentals, Media Coding and Content Processing", Prentice-Hall inc.

Usman Ahmad, 2005, "Pengolahan Citra Digital dan Teknik Pemrogramannya", Graha Ilmu, Yogyakarta.

Darah, https://id.wikipedia.org/wiki/Dara $\mathrm{h}$, diakses tanggal 20 Januari 2016. 